\title{
ANALIZA WŁAŚCIWOŚCI TECHNICZNYCH XIX-WIECZNYCH CEGIEt CERAMICZNYCH Z OBIEKTU ZABYTKOWEGO
}

\author{
Konrad Podawca ${ }^{\bowtie}$, Dominik Zakrzewski \\ Wydział Budownictwa i Inżynierii Środowiska, Szkoła Główna Gospodarstwa Wiejskiego w Warszawie, Warszawa
}

\begin{abstract}
STRESZCZENIE
W artykule przedstawiono badania właściwości fizycznych i mechanicznych cegieł pobranych z przegród wewnętrznych budynku wzniesionego w 1895 roku w Warszawie, przy al. Szucha 17/19. Celem analizy była charakterystyka i porównanie właściwości ponad 120-letnich elementów murowych z właściwościami obecnie produkowanych wyrobów budowlanych. Analiza obejmowała określenie takich cech, jak: wymiary i kształt, nasiąkliwość, mrozoodporność, gęstość objętościowa, gęstość właściwa, porowatość i wytrzymałość na ściskanie. Na podstawie wyników sporządzono deklaracje właściwości użytkowych badanych elementów w odniesieniu do obowiązujących wymagań.
\end{abstract}

Słowa kluczowe: ceramika, cegła pełna, właściwości techniczne, zabytek

\section{WSTĘP}

Wiele murowanych obiektów pochodzących z przełomu wieków XIX i XX podlega procesom renowacji i przebudowy. Może to powodować zmianę sposobu obciążenia, a więc poziom wytężenia konstrukcji nośnej po remoncie może okazać się większy niż zakładano pierwotnie. Podobna sytuacja obserwowana jest, gdy zmieniają się warunki, w jakich konstrukcja „pracuje” (np. powstanie w jej sąsiedztwie nowych dróg lub linii kolejowych). Brak dostatecznej wiedzy na temat cech dawnych ceramicznych materiałów budowlanych (głównie wytrzymałości murów) jest przyczyną wielu awarii konstrukcji remontowanych obiektów. Ważna jest więc prawidłowa ocena stanu remontowanej konstrukcji, w tym materiałów, z których jest zbudowana.

Prawidłowa ocena właściwości technicznych materiałów ceramicznych jest dodatkowo ważna w kontekście obiektów zabytkowych. Budynki objęte ochroną konserwatorską są często położone na atrakcyjnych inwestycyjnie działkach, a właściciele czy inwestorzy najchętniej zburzyliby takie obiekty. Takimi negatywnymi zdarzeniami była rozbiórka sąsiadującego z Łazienkami Królewskimi 100-letniego budynku z nieotynkowanej cegły koszar Pułku Huzarów Grodzieńskich przy ul. 29 Listopada 5 czy zmiana „w górę gruzu” przedwojennego domu przy ul. Felińskiego 39, w sercu Żoliborza. Takie sytuacje są jednoznacznym dowodem, że wydawanie pozwoleń na rozbiórkę obiektów zabytkowych nie powinno mieć miejsca bez wcześniejszych badań i określenia stanu technicznego.

\footnotetext{
${ }^{凶}$ konrad_podawca@sggw.pl 


\section{CEL I ZAKRES BADAŃ}

Celem badań jest określenie cech technicznych ponad 120-letnich cegieł pełnych pobranych z obiektu zabytkowego oraz wykonanie analizy porównawczej ich właściwości z wymogami stawianymi obecnie produkowanym wyrobom. Próby podobnych analiz były już wykonane przez wielu autorów (Rutkowska i Kijanka, 2010; Gruszczyński i Matysek, 2011; Matysek i Witkowski, 2013). Na podstawie literatury przedmiotu (Gantner, Wrońska, Wędrychowski i Nicewicz, 2000; Chojczak, 2016), norm oraz możliwości laboratoryjnych ustalono etapy postępowania.

Zakres badań obejmował empiryczne sprawdzenie cech fizycznych i mechanicznych populacji 20 sztuk cegieł. Badania zostały wykonane w Laboratorium Katedry Inżynierii Budowlanej, Wydziału Budownictwa i Inżynierii Środowiska, Szkoły Głównej Gospodarstwa Wiejskiego w Warszawie. Obejmowały one następujący zakres:

- badania właściwości fizycznych

- wymiary i kształt (PN-EN 772-16:2011),

- nasiąkliwość - absorpcja wody (PN-EN 772-21:2011),

- mrozoodporność - trwałość (PN-B-12012:2007),

- gęstość objętościowa (PN-EN 772-13:2011),

- gęstość właściwa (PN-76/B-06714-02:1976),

- porowatość,

- badania właściwości mechanicznych

- wytrzymałość na ściskanie (PN-EN 772-1:2011).

\section{MATERIAŁ I METODY}

Obiektem, z którego pochodzą próbki, jest neorenesansowy pałacyk znajdujący się w Warszawie, przy al. Szucha 17/19. Budynek powstał w 1895 roku dla generałowej Marii Agapijew. Na przestrzeni lat nieruchomość wielokrotnie zmieniała swoich właścicieli. Przed wojną mieszkał tam Andrzej Rotwand, znany bankowiec, inżynier i kolekcjoner sztuki, z żoną Marią, cenioną malarką. Po wojnie zgodnie z Dekretem z dnia 26 października 1945 roku o własności i użytkowaniu gruntów na obszarze m.st. Warszawy pałacyk stał się własnością gminy m.st. Warszawy. W 1960 roku nieruchomość została oddana do dyspozycji Ambasady ZSRR, w budynku powstało przedszkole dla dzieci radzieckich dyplomatów. W 2005 roku, po długoletnim procesie sądowym pałacyk odzyskała Maria Rotwand (Leśniakowska, 2005). Budynek przez wiele lat nie był objęty żadnym nadzorem, jego zły stan techniczny pogłębiał się. Dokonywano w nim wielu aktów wandalizmu. Często był miejscem noclegu bezdomnych. W 2012 roku pałacyk został wpisany do gminnej ewidencji zabytków m.st. Warszawy. W 2015 roku na terenie działki, na której znajduje się pałacyk, rozpoczęły się roboty związane z budową obiektu biurowego oraz renowacją pałacyku generałowej Marii Agapijew, które zakończone zostały w 2017 roku.

Pałacyk jest budynkiem podpiwniczonym, 2,5-kondygnacyjnym (piwnica, parter, pierwsze piętro, poddasze użytkowe). Jego ściany zostały wykonane w technologii murowanej z cegły ceramicznej pełnej.

Do badań użyto 20 cegieł ceramicznych wyprodukowanych w drugiej połowie XIX wieku. Pozyskano je podczas prac związanych z rozbiórką wewnętrznych przegród budynku. Próbki zostały podzielone na dwie grupy: połowa pochodzi z piwnicy, połowa z pierwszego piętra. Nie było możliwości pobrania całego fragmentu ściany.

Cegły zostały zmierzone za pomocą suwmiarki elektronicznej. W tabeli 1 podano największe wymiary poszczególnych elementów w każdym z trzech kierunków (PN-EN 772-16:2001). Założono, że wymiar nominalny badanych próbek to $270 \times 130 \times 70 \mathrm{~mm}(1 \times \mathrm{w} \times \mathrm{h})$. Takie cegły były produkowane na przełomie wieków XIX i XX (G.M., 1910). Próbka 10p1 pękła podczas pomiaru. 


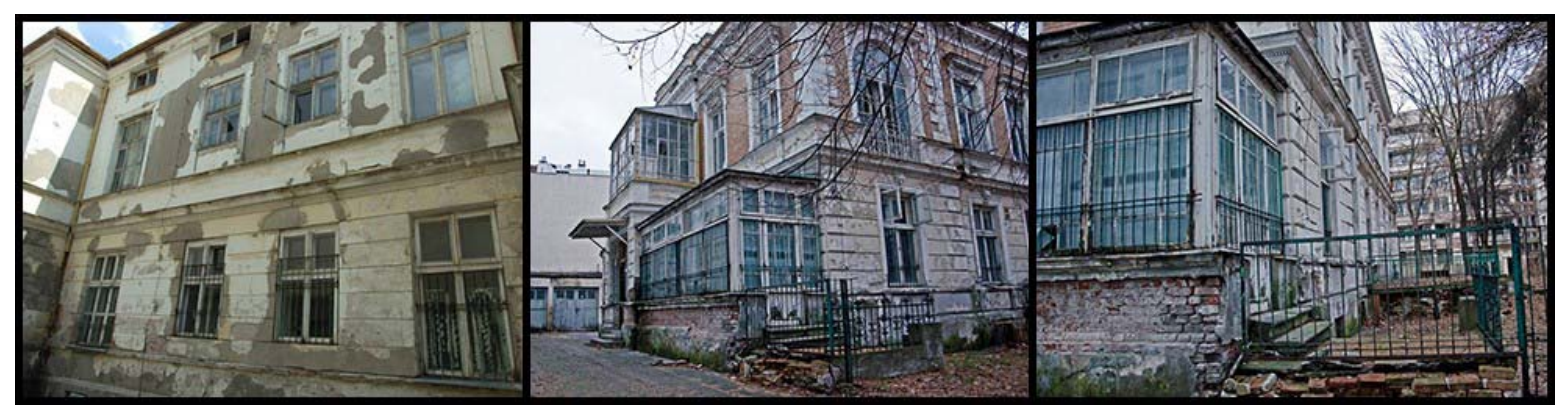

Rys. 1. Wygląd zewnętrzny pałacyku generałowej Marii Agapijew (fot. ERBUD S.A., 2015)

Fig. 1. Outer appearance of the general's lady Maria Agapijew palace (photo by ERBUD S.A., 2015)

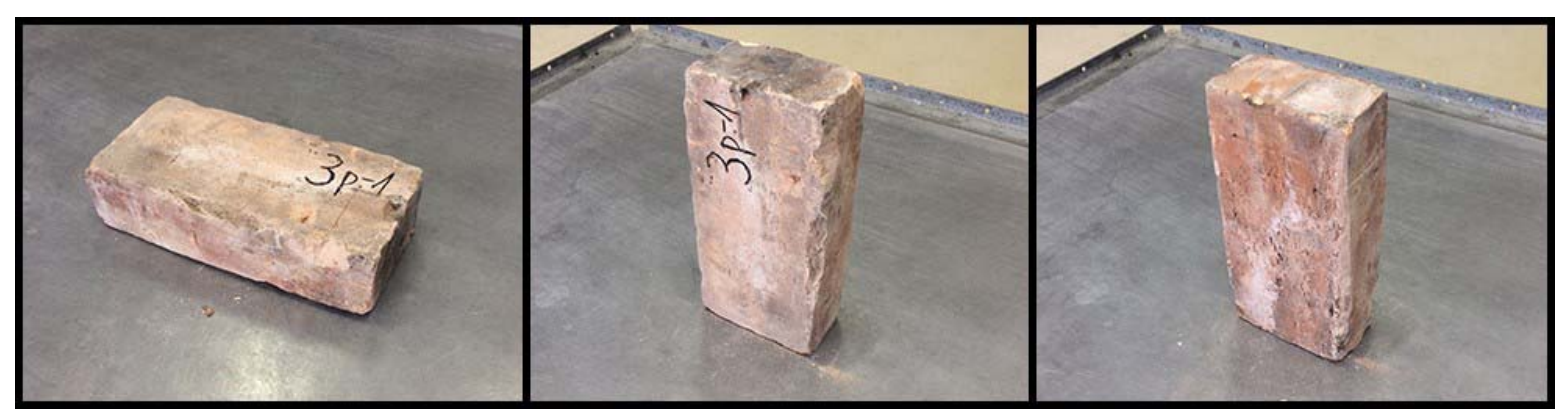

Rys. 2. Przykładowa cegła z piwnicy poddana badaniom (fot. D. Zakrzewski, 2016)

Fig. 2. Exemplary ceramic brick subjected to testing (photo by D. Zakrzewski, 2016)

Tabela 1. Wymiary próbek (opracowanie autorskie)

Table 1. Dimensions of bricks samples (own elaboration)

\begin{tabular}{|c|c|c|c|}
\hline \multirow{2}{*}{ Numer próbki - Number of sample } & \multicolumn{3}{|c|}{ Wymiar rzeczywisty próbki - Actual size of the sample [mm] } \\
\hline & a & $\mathrm{b}$ & $\mathrm{c}$ \\
\hline $1 \mathrm{p} 1$ & 273,33 & 129,44 & 68,59 \\
\hline $2 \mathrm{p} 1$ & 273,12 & 128,35 & 70,31 \\
\hline $3 \mathrm{p} 1$ & 275,17 & 133,49 & 70,68 \\
\hline $4 \mathrm{p} 1$ & 273,73 & 131,67 & 69,48 \\
\hline $5 \mathrm{p} 1$ & 266,69 & 129,19 & 66,85 \\
\hline $6 \mathrm{p} 1$ & 278,02 & 128,41 & 69,13 \\
\hline $7 \mathrm{p} 1$ & 273,59 & 132,11 & 68,40 \\
\hline $8 \mathrm{p} 1$ & 269,12 & 130,73 & 68,20 \\
\hline $9 \mathrm{p} 1$ & 266,02 & 121,12 & 66,02 \\
\hline 10p1 & 274,69 & 128,61 & 74,91 \\
\hline $1 \mathrm{p}-1$ & 266,59 & 136,92 & 69,14 \\
\hline $2 \mathrm{p}-1$ & 272,21 & 133,49 & 69,78 \\
\hline $3 p-1$ & 269,01 & 130,96 & 66,16 \\
\hline $4 p-1$ & 273,86 & 126,84 & 64,94 \\
\hline $5 p-1$ & 269,21 & 131,86 & 70,15 \\
\hline $6 \mathrm{p}-1$ & 268,17 & 129,88 & 67,16 \\
\hline $7 p-1$ & 268,80 & 136,32 & 71,38 \\
\hline $8 \mathrm{p}-1$ & 268,60 & 131,73 & 67,79 \\
\hline $9 \mathrm{p}-1$ & 271,94 & 131,12 & 68,76 \\
\hline $10 \mathrm{p}-1$ & 278,62 & 131,64 & 69,24 \\
\hline
\end{tabular}


Podawca, K., Zakrzewski, D. (2017). Analiza właściwości technicznych XIX-wiecznych cegieł ceramicznych z obiektu zabytkowego. Acta Sci. Pol. Architectura, 16 (4), 47-57. doi: 10.22630/ASPA.2017.16.4.05.

\section{WYNIKI}

Kolejność badań cech technicznych przystosowano do etapów rozdrabniania próbek. W pierwszej kolejności wykonano badania całych cegieł, tj.: ich nasiąkliwości, mrozoodporności, wytrzymałości na ściskanie. W przypadku nasiąkliwości objętościowej podano wyniki z wymiarów całej cegły oraz na podstawie objętości próbek nieforemnych wykorzystywanych do określenia gęstości objętościowej (tab. 2).

Tabela 2. Wyniki nasiąkliwości (opracowanie autorskie)

Table 2. Absorbability results (own elaboration)

\begin{tabular}{|c|c|c|c|c|c|}
\hline \multirow{2}{*}{$\begin{array}{l}\text { Numer próbki } \\
\text { Sample number }\end{array}$} & \multirow{2}{*}{$\begin{array}{l}\text { Masa próbki w stanie } \\
\text { suchym } \\
\text { Sample weight in dry } \\
\text { state } \\
{[\mathrm{kg}]}\end{array}$} & \multirow{2}{*}{$\begin{array}{c}\text { Masa próbki } \\
\text { nasyconej wodą } \\
\text { Weight of the sample } \\
\text { saturated with water } \\
{[\mathrm{kg}]}\end{array}$} & \multirow{2}{*}{$\begin{array}{c}\text { Nasiąkliwość masowa } \\
\text { Weight absorption } \\
{[\%]}\end{array}$} & \multicolumn{2}{|c|}{$\begin{array}{c}\text { Nasiąkliwość objętościowa } \\
\text { Volume absorption } \\
{[\%]}\end{array}$} \\
\hline & & & & A & B \\
\hline $1 \mathrm{p} 1$ & 3,545 & 4,396 & 24 & 35 & 37,7 \\
\hline $2 \mathrm{p} 1$ & 3,709 & 4,531 & 22 & 33 & 35,2 \\
\hline $3 \mathrm{p} 1$ & 3,752 & 4,572 & 22 & 32 & 38,5 \\
\hline $4 \mathrm{p} 1$ & 3,715 & 4,549 & 22 & 33 & 32,6 \\
\hline $5 \mathrm{p} 1$ & 3,194 & 3,948 & 24 & 33 & 40,2 \\
\hline $6 \mathrm{p} 1$ & 3,588 & 4,417 & 23 & 34 & - \\
\hline $7 \mathrm{p} 1$ & 3,485 & 4,32 & 24 & 34 & 39,7 \\
\hline $8 \mathrm{p} 1$ & 3,367 & 4,168 & 24 & 33 & - \\
\hline $9 \mathrm{p} 1$ & 3,503 & 4,037 & 15 & 25 & - \\
\hline 10p1 (a) & 1,733 & 2,146 & \multirow{2}{*}{24} & 34 & 39 \\
\hline $10 \mathrm{p} 1(\mathrm{~b})$ & 2,028 & 2,511 & & & \\
\hline $1 \mathrm{p}-1$ & 4,004 & 4,575 & 14 & 23 & 26,1 \\
\hline $2 \mathrm{p}-1$ & 3,694 & 4,666 & 26 & 38 & 42,2 \\
\hline $3 p-1$ & 3,516 & 4,425 & 26 & 39 & - \\
\hline $4 p-1$ & 3,361 & 4,094 & 22 & 32 & 34,9 \\
\hline $5 p-1$ & 3,525 & 4,428 & 26 & 36 & 38,5 \\
\hline $6 \mathrm{p}-1$ & 3,984 & 4,594 & 15 & 26 & - \\
\hline $7 \mathrm{p}-1$ & 3,99 & 4,637 & 16 & 25 & 27,2 \\
\hline $8 \mathrm{p}-1$ & 3,797 & 4,476 & 18 & 28 & 30,2 \\
\hline $9 p-1$ & 3,707 & 4,672 & 26 & 39 & 41,9 \\
\hline $10 p-1$ & 3,929 & 4,708 & 20 & 31 & - \\
\hline
\end{tabular}

Z analizowanego zbioru próbek wybrano sześć cegieł w najlepszym stanie wizualnym (6p1, 8p1, 9p1, 3p-1, 6p-1, 10p-1). Próbki umieszczono w pojemniku z wodą i nasączano do uzyskania stałej masy. Następnie powierzchnie cegieł osuszono z nadmiaru wody i umieszczono w komorze do badania mrozoodporności. Próbki były elementami nieelewacyjnymi, założono zatem 20 cykli zamrażania-odmrażania w zakresie temperatury od -18 do $5^{\circ} \mathrm{C}$. Badanie zostało przerwane po ośmiu cyklach ze względu na zniszczenie próbek (PN-B-12012:2007). 




Rys. 3. Próbki 10p-1, 8p1 i 3p-1 po badaniu mrozoodporności (fot. D. Zakrzewski, 2016)

Fig. 3. Samples 10p-1, 8p1 i 3p-1 after frost resistance testing (photo by D. Zakrzewski, 2016)

Z próbki laboratoryjnej pobrano 13 cegieł, które następnie poddano sezonowaniu do stanu powietrzno-suchego. Tak przygotowane elementy wyprawiono cienką warstwą zaprawy CX 20 i pozostawiono do wyschnięcia na $24 \mathrm{~h}$. Po upływie tego czasu zaprawa osiągnęła wytrzymałość $\geq 17 \mathrm{MPa}$. Badanie zostało przeprowadzone w maszynie wytrzymałościowej o zakresie do $1500 \mathrm{kN}$. Polegało ono na obciążaniu próbek aż do całkowitego ich zniszczenia. Na podstawie otrzymanych wyników obliczono znormalizowaną wytrzymałość na ściskanie (tab. 3). Według normy PN-EN 772-1:2011 współczynnik $\eta_{w}$ dla elementów w stanie powietrzno-suchym wynosi 1. Współczynnik kształtu $(\delta)$ przyjęto na podstawie interpolacji danych z tabeli 4.

Tabela 3. Wyniki wytrzymałości na ściskanie (opracowanie autorskie)

Table 3. Results of compressive strength (own elaboration)

\begin{tabular}{|c|c|c|c|c|c|}
\hline $\begin{array}{l}\text { Numer próbki } \\
\text { (cała cegła) } \\
\text { Number of sample } \\
\text { (the whole brick) }\end{array}$ & $\begin{array}{l}\text { Wynik badania } \\
\text { wytrzymałości na } \\
\text { ściskanie } \\
\text { Test result of } \\
\text { compressive } \\
\text { strength } \\
{[\mathrm{kN}]}\end{array}$ & $\begin{array}{c}\text { Pole podstawy } \\
\text { próbki } \\
\text { Sample base area } \\
{\left[\mathrm{mm}^{2}\right]}\end{array}$ & $\begin{array}{l}\text { Wytrzymałość na } \\
\text { ściskanie próbki } \\
\text { Compressive } \\
\text { strength } \\
\text { [MPa] }\end{array}$ & $\begin{array}{l}\text { Współczynnik } \\
\text { kształtu } \\
\text { Shape factor } \\
\delta\end{array}$ & $\begin{array}{c}\text { Znormalizowana } \\
\text { wytrzymałość na } \\
\text { ściskanie } \\
\text { Standard } \\
\text { compressive } \\
\text { strength } \\
\text { [MPa] }\end{array}$ \\
\hline $1 \mathrm{p} 1$ & 395 & 35379,84 & 11,16 & 0,81 & 9,03 \\
\hline $2 \mathrm{p} 1$ & 578 & 35054,95 & 16,49 & 0,82 & 13,44 \\
\hline $3 \mathrm{p} 1$ & 450 & 36732,44 & 12,25 & 0,81 & 9,92 \\
\hline $4 \mathrm{p} 1$ & 626 & 36042,03 & 17,37 & 0,80 & 13,94 \\
\hline $5 \mathrm{p} 1$ & 283 & 34453,68 & 8,21 & 0,80 & 6,57 \\
\hline $7 \mathrm{p} 1$ & 210 & 36143,97 & 5,81 & 0,80 & 4,64 \\
\hline $1 \mathrm{p}-1$ & 609,1 & 36501,50 & 16,69 & 0,79 & 13,23 \\
\hline $2 \mathrm{p}-1$ & 298 & 36337,31 & 8,20 & 0,80 & 6,60 \\
\hline $4 p-1$ & 151 & 34736,40 & 4,35 & 0,80 & 3,46 \\
\hline $5 p-1$ & 319 & 35498,03 & 8,99 & 0,81 & 7,25 \\
\hline $7 p-1$ & 323 & 36642,82 & 8,81 & 0,80 & 7,05 \\
\hline $8 \mathrm{p}-1$ & 324 & 35382,68 & 9,16 & 0,80 & 7,31 \\
\hline $9 p-1$ & 376 & 35656,77 & 10,54 & 0,81 & 8,49 \\
\hline
\end{tabular}


Podawca, K., Zakrzewski, D. (2017). Analiza właściwości technicznych XIX-wiecznych cegieł ceramicznych z obiektu zabytkowego. Acta Sci. Pol. Architectura, 16 (4), 47-57. doi: 10.22630/ASPA.2017.16.4.05.

Tabela 4. Współczynnik kształtu (PN-EN 772-1:2011)

Table 4. Shape factor (PN-EN 772-1:2011)

\begin{tabular}{|c|c|c|c|c|c|}
\hline \multirow{2}{*}{$\begin{array}{c}\text { Wysokość cegły } \\
\text { Brick height } \\
{[\mathrm{mm}]}\end{array}$} & \multicolumn{5}{|c|}{$\begin{array}{l}\text { Mniejszy wymiar elementu murowego - The smaller dimension of the masonry element } \\
{[\mathrm{mm}]}\end{array}$} \\
\hline & 50 & 100 & 150 & 200 & $\geq 250$ \\
\hline 40 & 0,80 & 0,70 & - & - & - \\
\hline 50 & 0,85 & 0,80 & 0,07 & - & - \\
\hline 65 & 0,95 & 0,85 & 0,75 & 0,70 & 0,65 \\
\hline 100 & 1,15 & 1,00 & 0,90 & 0,80 & 0,75 \\
\hline 150 & 1,30 & 1,20 & 1,10 & 1,00 & 0,95 \\
\hline 200 & 1,45 & 1,35 & 1,25 & 1,15 & 1,10 \\
\hline$\geq 250$ & 1,55 & 1,45 & 1,35 & 1,25 & 1,15 \\
\hline
\end{tabular}

Cegły po badaniu wytrzymałościowym rozdrobniono na 16 próbek o kształtach nieregularnych, a opisano analogicznie do cegieł, z których pochodziły. Suszono próbki w temperaturze $105-110^{\circ} \mathrm{C}$ do uzyskania stałej masy, a następnie zważono z dokładnością do $1 \mathrm{~g}$. Następnie próbki umieszczono w pojemniku z wodą i nasączano do uzyskania stałej masy. Objętość określono w szklanym objętościomierzu (tab. 5).

Tabela 5. Wyniki badania gęstości objętościowej (opracowanie autorskie)

Table 5. Results of volumetric density (own elaboration)

\begin{tabular}{cccc}
\hline $\begin{array}{c}\text { Numer próbki (elementy } \\
\text { o kształcie nieregularnym) } \\
\begin{array}{c}\text { Number of sample (elements } \\
\text { of irregular shape) }\end{array}\end{array}$ & $\begin{array}{c}\text { Masa próbek } \\
\text { Sample weight } \\
{[\mathrm{kg}]}\end{array}$ & $\begin{array}{c}\text { Objętość próbek } \\
\text { Volume of samples } \\
{\left[\mathrm{cm}^{3}\right]}\end{array}$ & $\begin{array}{c}\text { Gęstość objętościowa } \\
\text { Volumetric density } \\
{\left[\mathrm{kg} \cdot \mathrm{m}^{-3}\right]}\end{array}$ \\
\hline $1 \mathrm{p} 1$ & 0,077 & 60 & 1571,43 \\
\hline $2 \mathrm{p} 1$ & 0,096 & 40 & 1600,00 \\
\hline $3 \mathrm{p} 1$ & 0,07 & 58 & 1750,00 \\
\hline $4 \mathrm{p} 1$ & 0,086 & 34 & 1482,76 \\
\hline $5 \mathrm{p} 1$ & 0,057 & 32 & 1676,47 \\
\hline $7 \mathrm{p} 1$ & 0,053 & 40 & 1656,25 \\
\hline $10 \mathrm{p} 1$ & 0,065 & 43 & 1625,00 \\
\hline $10 \mathrm{p} 1 \mathrm{~A}$ & 0,07 & 44 & 1627,91 \\
\hline $1 \mathrm{p}-1$ & 0,082 & 45 & 1863,64 \\
\hline $2 \mathrm{p}-1$ & 0,073 & 63 & 1622,22 \\
\hline $4 \mathrm{p}-1$ & 0,1 & 54 & 1587,30 \\
\hline $5 \mathrm{p}-1$ & 0,08 & 50 & 1481,48 \\
\hline $7 \mathrm{p}-1$ & 0,085 & 39 & 1700,00 \\
\hline $7 \mathrm{p}-1 \mathrm{~A}$ & 0,064 & 50 & 1641,03 \\
\hline $8 \mathrm{p}-1$ & 0,084 & 62 & 1680,00 \\
\hline $9 \mathrm{p}-1$ & 0,1 & 1612,90 \\
\hline
\end{tabular}


Podawca, K., Zakrzewski, D. (2017). Analiza właściwości technicznych XIX-wiecznych cegieł ceramicznych z obiektu zabytkowego. Acta Sci. Pol. Architectura, 16 (4), 47-57. doi: 10.22630/ASPA.2017.16.4.05.

Następnie dwie próbki analityczne pochodzące z cegieł 5p-1 i 10p1 w ilości odpowiednio 200 i 240 g suszono do uzyskania stałej masy w suszarce w temperaturze $105-110^{\circ} \mathrm{C}$. Tak przygotowane elementy rozdrobniono w młynku dyskowym, przesiano przez sito o oczkach $0,063 \mathrm{~mm}$. W ustabilizowanej temperaturze powietrza i odczynnika $20^{\circ} \mathrm{C}$ określono objętość próbki wsypanej do kolby Le Chateliera (tab. 6).

Tabela 6. Wyniki badania gęstości właściwej (opracowanie autorskie)

Table 6. Results of unit density (own elaboration)

\begin{tabular}{|c|c|c|c|c|c|c|}
\hline \multirow{2}{*}{$\begin{array}{c}\text { Numer próbki } \\
\text { Number } \\
\text { of sample }\end{array}$} & \multirow{2}{*}{$\begin{array}{c}\text { Masa } \\
\text { parowniczki } \\
\text { Evaporator } \\
\text { weight } \\
{[\mathrm{kg}]} \\
\end{array}$} & \multicolumn{2}{|c|}{$\begin{array}{l}\text { Masa parowniczki i próbki } \\
\text { Evaporator and sample weight }\end{array}$} & \multirow{2}{*}{$\begin{array}{l}\text { Masa wsypanej } \\
\text { próbki } \\
\text { Weight of the } \\
\text { pouring sample } \\
{[\mathrm{kg}]}\end{array}$} & \multirow{2}{*}{$\begin{array}{c}\text { Objętość } \\
\text { wsypanej próbki } \\
\text { Volume of the } \\
\text { pumped sample } \\
{\left[\mathrm{cm}^{3}\right]}\end{array}$} & \multirow{2}{*}{$\begin{array}{c}\text { Gęstość } \\
\text { właściwa } \\
\text { Unit density } \\
{\left[\mathrm{kg} \cdot \mathrm{m}^{-3}\right]}\end{array}$} \\
\hline & & $\begin{array}{c}\text { przed badaniem } \\
\text { before the test }\end{array}$ & $\begin{array}{l}\text { po badaniu } \\
\text { after the test }\end{array}$ & & & \\
\hline $5 p-1$ & 0,332 & 0,5251 & 0,4751 & 0,05 & 18,5 & 2703 \\
\hline $10 \mathrm{p} 1 \mathrm{~A}$ & 0,284 & 0,5129 & 0,4587 & 0,0542 & 20,1 & 2697 \\
\hline 10p1B & 0,284 & 0,5129 & 0,4546 & 0,0583 & 21,6 & 2699 \\
\hline
\end{tabular}

Z wykorzystaniem pobadanej gęstości objętościowej i właściwej obliczono porowatość i szczelność badanych próbek ceramiki (tab. 7).

Tabela 7. Wyniki porowatości i szczelności poszczególnych próbek (opracowanie autorskie)

Table 7. Results of porosity and leakproofness (own elaboration)

\begin{tabular}{ccc}
\hline Numer próbki - Number of sample & $\begin{array}{c}\text { Szczelność - Leakproofness } \\
{[\%]}\end{array}$ & $\begin{array}{c}\text { Porowatość - Porosity } \\
{[\%]}\end{array}$ \\
\hline $1 p 1$ & 58,2 & 41,8 \\
\hline $2 p 1$ & 59,3 & 40,7 \\
\hline $3 p 1$ & 64,8 & 35,2 \\
\hline $4 p 1$ & 54,9 & 45,1 \\
\hline $5 p 1$ & 62,1 & 37,9 \\
\hline $7 p 1$ & 61,3 & 38,7 \\
\hline $10 p 1$ & 60,2 & 39,8 \\
\hline $10 p 1 A$ & 61,7 & 38,3 \\
\hline $1 p-1$ & 69,0 & 31,0 \\
\hline $2 p-1$ & 60,1 & 39,9 \\
\hline $4 p-1$ & 58,8 & 41,2 \\
\hline $5 p-1$ & 54,9 & 45,1 \\
\hline $7 p-1$ & 63,0 & 37,0 \\
\hline $7 p-1 A$ & 60,8 & 39,2 \\
\hline $8 p-1$ & 62,2 & 37,8 \\
\hline $9 p-1$ & 59,7 & 40,3 \\
\hline
\end{tabular}


Podawca, K., Zakrzewski, D. (2017). Analiza właściwości technicznych XIX-wiecznych cegieł ceramicznych z obiektu zabytkowego. Acta Sci. Pol. Architectura, 16 (4), 47-57. doi: 10.22630/ASPA.2017.16.4.05.

\section{ANALIZA WYNIKÓW}

W tabeli 8 przedstawiono zestawienie otrzymanych danych z kategoriami wymagań obecnych wyrobów. Na tej podstawie sklasyfikowano poszczególne badane cegły.

Tabela 8. Analiza porównawcza cech technicznych i mechanicznych cegły pełnej (opracowanie autorskie)

Table 8. Comparative analysis of technical and mechanical characteristics of full bricks (own elaboration)

\begin{tabular}{|c|c|c|c|c|c|c|c|c|}
\hline \multirow[b]{2}{*}{$\begin{array}{c}\text { Numer } \\
\text { próbki } \\
\text { Number } \\
\text { of sample }\end{array}$} & \multicolumn{2}{|c|}{$\begin{array}{l}\text { Odchyłki wymiarów } \\
\text { Dimensions of deviation }\end{array}$} & \multicolumn{2}{|c|}{$\begin{array}{l}\text { Wytrzymałość na ściskanie } \\
\text { Compressive strength }\end{array}$} & \multirow{2}{*}{ 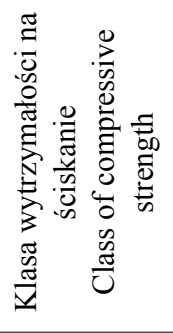 } & \multirow{2}{*}{ 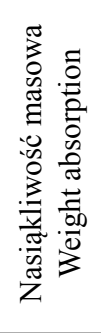 } & \multirow{2}{*}{ 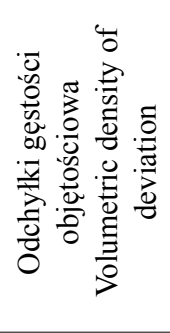 } & \multirow[b]{2}{*}{  } \\
\hline & $\begin{array}{c}\text { kategoria } \\
\text { odchyłek } \\
\text { wymiarów } \\
\text { category of } \\
\text { dimensions of } \\
\text { deviation }\end{array}$ & $\begin{array}{l}\text { kategoria } \\
\text { rozpiętości } \\
\text { wymiarów } \\
\text { category } \\
\text { of span } \\
\text { dimensions }\end{array}$ & $\begin{array}{l}\text { zbadana } \\
\text { examined }\end{array}$ & standard & & & & \\
\hline $1 \mathrm{p} 1$ & $\mathrm{~T} 2$ & $\mathrm{R} 2$ & 11,16 & 9,03 & 7,5 & 24 & Dm $15 \%$ & F0 \\
\hline $2 \mathrm{p} 1$ & $\mathrm{~T} 2$ & $\mathrm{R} 2$ & 16,49 & 13,44 & 10 & 22 & D1 & F0 \\
\hline $3 \mathrm{p} 1$ & $\mathrm{~T} 1$ & $\mathrm{R} 1$ & 12,25 & 9,92 & 7,5 & 22 & $\mathrm{D} 2$ & F0 \\
\hline $4 \mathrm{p} 1$ & $\mathrm{~T} 2$ & $\mathrm{R} 2$ & 17,37 & 13,94 & 10 & 22 & D1 & F0 \\
\hline $5 \mathrm{p} 1$ & $\mathrm{~T} 1$ & $\mathrm{R} 1$ & 8,21 & 6,57 & 5 & 24 & $\mathrm{D} 2$ & F0 \\
\hline $6 \mathrm{p} 1$ & $\operatorname{Tm} 0,5$ & R1 & - & - & - & 23 & D1 & F0 \\
\hline $7 \mathrm{p} 1$ & $\mathrm{~T} 2$ & $\mathrm{R} 2$ & 5,81 & 4,64 & - & 24 & D2 & F0 \\
\hline $8 \mathrm{p} 1$ & $\mathrm{~T} 2$ & $\mathrm{R} 2$ & - & - & - & 24 & D1 & F0 \\
\hline $9 \mathrm{p} 1$ & $\operatorname{Tm} 0,8$ & $\mathrm{Rm} 0,8$ & - & - & - & 15 & D1 & F0 \\
\hline $10 \mathrm{p} 1$ & $\operatorname{Tm} 0,6$ & $\mathrm{R} 1$ & - & - & - & 24 & D1 & F0 \\
\hline $1 \mathrm{p}-1$ & $\operatorname{Tm} 0,65$ & Rm 0,65 & 16,69 & 13,23 & 10 & 14 & D1 & F0 \\
\hline $2 p-1$ & $\mathrm{~T} 1$ & R1 & 8,20 & 6,6 & 5 & 26 & D1 & F0 \\
\hline $3 p-1$ & $\operatorname{Tm} 0,5$ & $\mathrm{R} 1$ & - & - & - & 26 & D1 & F0 \\
\hline $4 p-1$ & $\operatorname{Tm} 0,65$ & $\mathrm{Rm} 0,65$ & 4,35 & 3,46 & - & 22 & D1 & F0 \\
\hline $5 p-1$ & $\mathrm{~T} 2$ & $\mathrm{R} 2$ & 8,99 & 7,25 & 5 & 26 & Dm $15 \%$ & F0 \\
\hline $6 \mathrm{p}-1$ & $\mathrm{~T} 1$ & $\mathrm{R} 1$ & - & - & - & 15 & D1 & F0 \\
\hline $7 p-1$ & $\operatorname{Tm} 0,6$ & R1 & 8,81 & 7,05 & 5 & 16 & D1 & F0 \\
\hline $8 \mathrm{p}-1$ & $\mathrm{~T} 1$ & $\mathrm{R} 2$ & 9,16 & 7,31 & 5 & 18 & $\mathrm{D} 2$ & F0 \\
\hline $9 p-1$ & $\mathrm{~T} 2$ & $\mathrm{R} 2$ & 10,54 & 8,49 & 7,5 & 26 & D1 & F0 \\
\hline $10 p-1$ & $\operatorname{Tm} 0,55$ & $\mathrm{R} 1$ & - & - & - & 20 & D1 & F0 \\
\hline
\end{tabular}

W kontekście oceny posiadanego materiału badawczego postanowiono scharakteryzować go pod kątem dzisiejszych wymogów w odniesieniu do pojedynczych sztuk cegieł.

Pod względem kategorii odchyłek i rozpiętości wymiarów za wymiar nominalny przyjęto $270 \times 130 \times 70 \mathrm{~mm}$, a poszczególne kategorie zgodnie z zasadami normowymi (Chojczak, 2016):

- T1 - $3 \mathrm{~mm}$ lub $\pm 0,40 \sqrt{ }$ (wymiar nominalny),

- $\mathrm{T} 2$ - $2 \mathrm{~mm}$ lub $\pm 0,25 \sqrt{ }$ (wymiar nominalny), 
- Tm - deklarowane odchyłki przez producenta [mm], które mogą być mniejsze lub większe od innych kategorii,

- $\mathrm{R} 1 \pm 0,60 \sqrt{ }$ (wymiar nominalny),

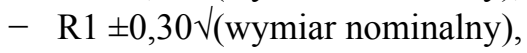

- Rm - deklarowana przez producenta rozpiętość [mm], która może być mniejsza lub większa od przyjętych dla innych kategorii.

W odniesieniu do odchyłek gęstości założono kategorie zgodnie z zasadą, 10\% różnicy D1, 5\% różnicy D2, a odchyłka Dm [\%] większa lub mniejsza od D1 i D2, w odniesieniu do wartości $1730 \mathrm{~kg} \cdot \mathrm{m}^{-3}$.

Przy klasach wytrzymałości klasyfikowano cegłę ceramiczną według wartości znormalizowanej. Spośród próbek, dla których wykonano badanie wytrzymałościowe, tylko jedną nie dało się sklasyfikować pod kątem wytrzymałości na ściskanie. Niestety nie udało się pozytywnie przeprowadzić badania mrozoodporności. Przyjęto więc, że wszystkie cegły mają trwałość F0, czyli założono pracę w warunkach obojętnych.

\section{WNIOSKII PODSUMOWANIE}

Cegły pochodzące z XIX wieku były większe niż obecne. Dwanaście próbek spełnia typową dla cegły pełnej kategorię odchyłek wymiarów T1 lub T2, niestandardowe kategorie rozpiętości wymiarów zastosowano dla trzech elementów. Analiza wszystkich próbek pokazuje, że różnice między największą a najmniejszą wartością danego wymiaru są znaczne. Średnia długość badanych cegieł wynosi 271,52 mm; szerokość 130,69 mm; wysokość $68,85 \mathrm{~mm}$. Odchylenia standardowe wynoszą odpowiednio 3,70 (1,36\%); 3,39 (2,60\%) i 2,19 (3,18\%). Dowodzi to, że wymogi stawiane cegle ceramicznej w XIX wieku były mniej restrykcyjne niż obecnie i dopuszczały większą niedokładność wymiarów gotowych wyrobów.

Średnia nasiąkliwość masowa badanych próbek wynosi 22\%, odchylenie standardowe jest równe 3,98 $(18,37 \%)$. Większy rozrzut tego parametru zaobserwowano w próbkach pochodzących z piwnicy - gdzie różnica między próbkami o największej nasiąkliwości $(2 \mathrm{p}-1 ; 3 \mathrm{p}-1 ; 5 \mathrm{p}-1 ; 9 \mathrm{p}-1)$ a próbką o najmniejszej nasiąkliwości (1p-1) wynosi 12\%. Nasiąkliwość większości próbek z pierwszego piętra odbiega od wartości średniej o maksymalnie 2 p.p. Wyjątkiem jest próbka 9p1 o nasiąkliwości 15\%. Wyniki nasiąkliwości objętościowej wykazują podobną tendencję. Średnia nasiąkliwość objętościowa wynosi 32\%, odchylenie standardowe jest równe 4,63 (14,39\%). Podobnie jak w przypadku nasiąkliwości masowej, próbki pochodzące z pierwszego piętra są bliższe wartości średniej. Wartości nasiąkliwości objętościowej obliczone na podstawie gęstości pozornej różnią się od wartości obliczonych na podstawie zmierzonych wymiarów cegieł o 2-6 p.p.

Cegły użyte do badań były częścią wewnętrznych przegród budynku, a więc w warunkach docelowego zastosowania nie były narażone na oddziaływanie wilgoci i mrozu. Obecnie dla elementów tego typu nie stosuje się wymogów dotyczących odporności na cykliczne zamrażanie i odmrażanie. Niemniej widać, że liczne akty wandalizmu, brak ogrzewania budynku, zniszczona stolarka okienna wpłynęły na oddziaływanie czynników atmosferycznych na badane cegły. Mogło to spowodować zniszczenie próbek w badaniu mrozoodporności.

Średnia wartość wytrzymałości na ściskanie wynosi 10,62 MPa, odchylenie standardowe jest równe 4,1 $(38,64 \%)$. Średnia wartość znormalizowanej wytrzymałości na ściskanie wynosi 8,53 MPa, odchylenie standardowe jest równe 3,31 (38,78\%). Dwie z trzynastu badanych cegieł nie zostały przyporządkowane do żadnej klasy wytrzymałości na ściskanie (7p1 i 4p-1). Żadna z próbek nie przekroczyła 10 klasy. Badane elementy murowe przez wiele lat były narażone na niekorzystne warunki pracy. Wielokrotne cykle zamarzania i odmarzania, kontakt z wilgocią oraz wiek znacząco wpłynęły na ich właściwości wytrzymałościowe. Można jednak stwierdzić, że w momencie budowy pałacyku cegły spełniały ówczesne standardy wytrzymałości na ściskanie (Borusiewicz, 1985).

Średnia gęstość pozorna badanych próbek wynosi $1636,15 \mathrm{~kg} \cdot \mathrm{m}^{-3}$, odchylenie standardowe jest równe 92,75 $(5,67 \%)$. Większy rozrzut wyników wokół średniej zaobserwowano w próbkach pochodzących z piwnicy. 
Gęstość właściwa jednoznacznie ukazała zakwalifikowanie cegieł do grupy ceramiki czerwonej.

Średnia szczelność badanych próbek wynosi 60,7\% - najmniejszy otrzymany wynik wynosi 54,9\%, największy $69 \%$.

Średnia wartość porowatości badanych próbek wynosi 39,3\% - najmniejszy otrzymany wynik wynosi 31\%, największy $45,1 \%$. Nie zaobserwowano zależności między porowatością materiału a jego wytrzymałością na ściskanie. Znaleziono przykłady zarówno cegieł o małej wytrzymałości, a także małej porowatości (7p1), jak i dużej wytrzymałości oraz dużej porowatości (4p1).

Wyniki przeprowadzonych badań tylko w pewnym zakresie mogą potwierdzić słuszność decyzji o rozbiórce murowanej konstrukcji nośnej pałacyku. Wykazano duże różnice między właściwościami technicznymi poszczególnych wyrobów. Badane cegły nie spełniają obecnych standardów, przez co dokładne określenie nośności murów jest zadaniem bardzo trudnym. Adaptacja dawnej konstrukcji do nowej funkcji mogłaby zmienić zakładany pierwotnie układ obciążeń, co mogłoby być przyczyną katastrofy budowlanej. O ostatecznej decyzji rozbiórkowej powinny jednak wyrokować badania fragmentów przegrody, na podstawie których można wyrokować o stopniu zużycia technicznego muru i zagrożeniach nośności. Niestety nie było możliwości pobrania fragmentów muru czy odwiertów w celu sprawdzenia ich nośności.

\section{PIŚMIENNICTWO}

Borusiewicz, W. (1985). Konserwacja zabytków budownictwa murowanego. Warszawa: Arkady.

Gantner, E., Wrońska, Z., Wędrychowski, W. i Nicewicz, S. (2000). Materiały budowlane z technologia betonu: ćwiczenia laboratoryjne. Warszawa: Oficyna Wydawnicza Politechniki Warszawskiej.

G.M. (1910). Cegła z piasku. Przemystowiec, 48, 383.

Chojczak, W. (2016). Materiały budowlane. Ćwiczenia laboratoryjne. Cz. 1. W Właściwości techniczne, kamień naturalny, ceramika (strony 151-158). Warszawa: Wydawnictwo Oficyna Wydawnicza Politechniki Warszawskiej.

Gruszczyński, M. i Matysek, P. (2011). Ocena wytrzymałości murów ceglanych na podstawie badań odwiertów rdzeniowych. Czasopismo Techniczne, Budownictwo, 108, 3-B, 57-69.

Leśniakowska, M. (2005). Architektura w Warszawie. Warszawa: Arkada Pracownia Historii Sztuki.

Matysek, P. i Witkowski, M. (2013). Badania wytrzymałości i odkształcalności XIX-wiecznych murów ceglanych. W Konferencja Naukowo-Techniczna „Awarie budowlane XXVI”, Międzyzdroje.

PN-76/B-06714-02:1976. Kruszywa mineralne - Badania - Oznaczanie gęstości w kolbie Le Chateliera.

PN-B-12012:2007. Metody badań elementów murowych - Określanie odporności na zamrażanie-odmrażanie elementów murowych ceramicznych.

PN-EN 772-1:2011. Metody badań elementów murowych - Część 1: Określenie wytrzymałości na ściskanie.

PN-EN 772-13:2011. Metody badań elementów murowych - Część 13: Określenie gęstości netto i gęstości brutto elementów murowych w stanie suchym (z wyjątkiem kamienia naturalnego).

PN-EN 772-16:2001. Metody badań elementów murowych - Część 16: Określanie wymiarów.

PN-EN 772-21:2011. Metody badań elementów murowych - Część 21: Określanie absorpcji wody ceramicznych i silikatowych elementów murowych przez absorpcję zimnej wody.

Rutkowska, G. i Kijanka, P. (2010). Analiza porównawcza wybranych cech technicznych cegieł pełnych na przykładach budynków jednorodzinnych. Acta Scientarum Polonorum, Architectura 9 (2), 35-44. 


\section{ANALYSIS OF TECHNICAL FEATURES OF 19TH-CENTURY CERAMIC BRICKS FROM A HISTORIC MONUMENT}

\section{ABSTRACT}

The article presents the physical and mechanical properties of bricks taken from internal partitions of a building erected in 1895 in Warsaw, al. Jan Chrystian Szucha 17/19. The purpose of the analysis was to characterize and compare the properties of over 120-years-old masonry elements with the properties of currently manufactured products. The analysis included the determination of features, such as: dimensions and shape, absorbability, frost resistance, volumetric density, unit density, porosity and compressive strength. On the basis of the results, the declarations of performance of the tested elements were drawn up in relation to the applicable requirements.

Key words: ceramics, full brick, technical properties, historical monuments 